
Kidney
Blood Pressure Research

\begin{tabular}{|c|c|}
\hline Kidney Blood Press Res 2017;4 & \\
\hline $\begin{array}{l}\text { DOI: 10.1159/000485865 } \\
\text { Published online: December 11, } 2017\end{array}$ & $\begin{array}{l}\text { (c) } 2017 \text { The Author(s) } \\
\text { Published by S. Karger AG, Basel } \\
\text { www.karger.com/kbr }\end{array}$ \\
\hline
\end{tabular}

\title{
Serum Hepcidin and Iron Indices Affect Anemia Status Differently According to the Kidney Function of Non-Dialysis Chronic Kidney Disease Patients: Korean Cohort Study For Outcome in Patients with Chronic Kidney Disease (KNOW-CKD)
}

\author{
Sung Woo Lee ${ }^{a, b}$ Yeong Hoon Kim ${ }^{c}$ Wookyung Chung ${ }^{d}$ Sue K. Park ${ }^{\text {ef, }}$ \\ Dong Wan Chae ${ }^{\mathrm{h}}$ Curie Ahn ${ }^{\mathrm{h}}$ Yong-Soo Kim ${ }^{\mathrm{i}}$ Su Ah Sung ${ }^{\mathrm{b}}$
}

\begin{abstract}
${ }^{a}$ Department of Internal Medicine, Seoul National University Postgraduate School, bepartment of Internal Medicine, Eulji Medical Center, Eulji University, Seoul, cDepartment of Internal Medicine, Inje University, Busan Paik Hospital, Busan, dDepartment of Internal Medicine, Gachon University, Gil Hospital, Incheon, eDepartment of Preventive Medicine, Seoul National University College of Medicine, ${ }^{\mathrm{f}}$ Cancer Research Institute, Seoul National University, ${ }^{9}$ Department of Biomedical Science, Seoul National University Graduate School, hDepartment of Internal Medicine, Seoul National University College of Medicine, 'Department of Internal Medicine, Catholic University of Korea, Seoul St. Mary's Hospital, Seoul, Korea
\end{abstract}

\section{Key Words}

Transferrin saturation • Ferritin • Hepcidin • Anemia • Severity

\begin{abstract}
Background/Aims: No studies have examined the association among serum hepcidin, iron indices, or anemia status based on the kidney function of non-dialysis chronic kidney disease (CKD) patients. Methods: We reviewed data of 2238 patients from a large-scale multicenter prospective Korean study (2011-2016) and excluded 198 patients with missing data regarding serum hepcidin, hemoglobin, transferrin saturation (TSAT), ferritin, and usage of erythropoiesisstimulating agents (ESA) or supplemental iron and 363 patients using ESA or supplemental iron. Finally, 1677 patients were included. Results: The mean patient age was 53.5 years, and $65.4 \%$ were men. TSAT and serum hepcidin were significantly associated with anemia status, whereas serum ferritin was not, regardless of anemia severity. For patients with an estimated glomerular filtration rate (eGFR) $\geq 45 \mathrm{~mL} / \mathrm{min} / 1.73 \mathrm{~m}^{2}$, a $10 \%$ increase of TSAT was associated
\end{abstract}




\section{Kidney Blood Pressure Research}

Lee et al.: Serum Hepcidin and Anemia of CKD

with hemoglobin $<13 \mathrm{~g} / \mathrm{dL}$ (odds ratio [OR], 0.628; 95\% confidence interval [CI], 0.515-0.765; $P<0.001)$ and hemoglobin $<11.5 \mathrm{~g} / \mathrm{dL}(\mathrm{OR}, 0.672 ; 95 \% \mathrm{CI}, 0.476-0.950 ; P=0.024)$, whereas a $10-\mathrm{ng} / \mathrm{mL}$ increase of serum hepcidin was associated with hemoglobin $<11.5 \mathrm{~g} / \mathrm{dL}$ (OR, 1.379; 95\% CI, 1.173-1.620; $P<0.001)$ and hemoglobin $<10.0 \mathrm{~g} / \mathrm{dL}(\mathrm{OR}, 1.360 ; 95 \% \mathrm{CI}, 1.115-$ 1.659; $P=0.002$ ) for patients with eGFR $<45 \mathrm{~mL} / \mathrm{min} / 1.73 \mathrm{~m}^{2}$ according to multivariate logistic analysis. Conclusions: TSAT was associated with less severe anemia in early CKD patients. Serum hepcidin was associated with more severe anemia in advanced CKD patients.

(C) 2017 The Author(s)

Published by S. Karger AG, Basel

\section{Introduction}

The prevalence of anemia is higher among patients with chronic kidney disease (CKD) than among the general population [1]. Furthermore, anemia tends to be more severe in patients with more advanced CKD [1,2]. Because anemia in CKD patients contributes to an increased risk of end-stage renal disease (ESRD), cardiovascular events, and death [3,4], the identification of factors associated with anemia in CKD patients is important. The major factor contributing to anemia in CKD patients is erythropoietin deficiency. Erythropoietin is produced by renal interstitial fibroblasts and stimulates red blood cell (RBC) production in the bone marrow [5]. As CKD progresses, erythropoietin levels are inappropriate for the level of anemia, and normocytic, normochromic, and hypo-proliferative anemia can develop [5]. To correct erythropoietin deficiency, studies have attempted to normalize hemoglobin ( $\mathrm{Hb}$ ) levels by replacing erythropoietin [6-9], but they ultimately failed to improve the clinical outcomes $[6,7]$.

Recently, iron metabolism has been suggested as another factor contributing to anemia in CKD patients $[10,11]$. Conventionally, transferrin saturation (TSAT) and ferritin have been used as serum iron indices $[12,13]$. TSAT, which is the ratio of serum iron and total iron- binding capacity, is a marker of the available serum iron, and serum levels of ferritin, which is an intracellular iron storage protein, indirectly indicate whole-body iron storage $[10,14]$. However, the effectiveness of these two iron indices for anemia in CKD patients is inconclusive [15-18]. In this regard, hepcidin may be a better biomarker of anemia in CKD patients than conventional iron indices because it is more fundamental; hepcidin lowers available serum iron levels by limiting iron efflux from whole-body iron storage $[19,20]$. Although previous studies have suggested the important role of hepcidin in anemia in nondialysis [21-28] and dialysis [29-33] CKD patients, many relied on small population samples from single centers. No studies have explored the differential associations of hepcidin and iron indices with anemia according to the severity of anemia and kidney function. Because the serum hepcidin level is affected by kidney function [20], we hypothesized that hepcidin and iron indices are differentially associated with anemia in non-dialysis CKD patients according to kidney function. We also hypothesized that because iron is sequestrated by hepcidin [19], anemia associated with hepcidin is more severe than anemia associated with iron indices.

\section{Materials and Methods}

\section{Participants}

The KoreaN cohort study for Outcome in patients With Chronic Kidney Disease (KNOW-CKD) is a multicenter, prospective cohort study in Korea of 2238 non-dialysis patients with CKD stages 1-5 who were enrolled between February 2011 and January 2016. The detailed design and methods of the KNOWCKD were previously published (NCT01630486 at http://www.clinicaltrials.gov) [34]. The protocol of the KNOW-CKD adhered to the principles of the Declaration of Helsinki and was approved by the institutional review board at each participating hospital, including Seoul National University Hospital, Yonsei University Severance Hospital, Kangbuk Samsung Medical Center, Seoul St. Mary's Hospital, Gil Hospital, Eulji Medical 


\section{Kidney \\ Blood Pressure Research}

Center, Chonnam National University Hospital, and Busan Paik Hospital. Written informed consent was obtained from all subjects. The estimated glomerular filtration rate (eGFR) was calculated by the equation of Modification of Diet in Renal Disease study formula [35]. CKD and its stages were defined using the Kidney Disease Improving Global Outcomes (KDIGO) 2012 guidelines [36].

Of the 2238 patients, 561 were excluded: 198 with missing data regarding serum hepcidin, Hb, TSAT, ferritin, and usage of erythropoiesis-stimulating agents (ESA) or supplemental iron and 363 patients who had used ESA or supplemental iron. Therefore, 1677 patients were included in the final analysis.

\section{Serum hepcidin measurement}

Serum hepcidin levels were measured at a central laboratory with competitive enzyme-linked immunosorbent assay using EIA5258 kits (DRG Diagnostics, Marburg, Germany) according to the manufacturer's instructions. The intra-assay and inter-assay coefficients of variation ranged from $2.1 \%$ to $9.9 \%$ and from $11.5 \%$ to $14.6 \%$, respectively [20]. The detectable maximum level was $80 \mathrm{ng} / \mathrm{mL}$; therefore, higher levels were recorded as $80 \mathrm{ng} / \mathrm{mL}$.

\section{Definitions}

Clinical data, including detailed demographic information and baseline laboratory results, were extracted from an electronic data management system (PhactaX). Hypertension was defined as systolic blood pressure (BP) $\geq 140 \mathrm{~mm} \mathrm{Hg}$ or diastolic BP $\geq 90 \mathrm{mmHg}$ or treatment with anti-hypertensive drugs. Diabetes was defined as fasting glucose $\geq 126 \mathrm{mg} / \mathrm{dL}$, or treatment with insulin or oral anti-diabetic drugs. The ever smoking status was defined as past or current smoking. High income was defined as a monthly household income of more than KRW 4.5 million (approximately USD 4000). Body mass index (BMI) was calculated as weight $(\mathrm{kg})$ per square meter of height $\left(\mathrm{m}^{2}\right)$. TSAT $(\%)$ was calculated as serum iron $\times 100 /$ total iron binding capacity. The study outcome was anemia severity defined by the necessity of ESA: Hb $<13.0 \mathrm{~g} / \mathrm{dL}$ (ESA should not be used to increase Hb levels intentionally), $\mathrm{Hb}<11.5 \mathrm{~g} / \mathrm{dL}$ (ESA should be used to maintain $\mathrm{Hb}$ levels), and $\mathrm{Hb}<10.0 \mathrm{~g} / \mathrm{dL}$ (ESA should be started), as stated by the KDIGO 2012 anemia guidelines [37]. Early and advanced CKD were defined as eGFR $\geq 45$ and $<45 \mathrm{~mL} / \mathrm{min} / 1.73 \mathrm{~m}^{2}$, respectively [20].

\section{Statistical analysis}

Variables are expressed as mean \pm standard deviation for continuous variables with normal distribution, median (interquartile range) for continuous variables with non-normal distribution and percentage for categorical variables. The odds ratio (OR) and 95\% confidence interval (CI) were analyzed using logistic regression analysis. During multivariate analysis, variables associated with anemia status during univariate logistic regression were selected as covariates, along with white blood cells and C-reactive protein. The area under the curve (AUC) and its 95\% CI of the receiver-operating characteristics (ROC) curve were evaluated using R version 3.03 (2014; R Core Team) with "pROC" packages [38]. Comparisons between two AUCs were performed using the DeLong test [39]. All analyses, unless otherwise specified, were performed using SPSS version 22 (2013; IBM Corp., Armonk, NY).

\section{Results}

The mean age of the 1677 patients was 53.5 years, and $65.4 \%$ were men. The mean eGFR was $54.8 \mathrm{~mL} / \mathrm{min} / 1.73 \mathrm{~m}^{2}$, with a median urine protein-to-creatinine ratio (UPCR) of $0.4 \mathrm{~g} / \mathrm{g}$ creatinine. The mean $\mathrm{Hb}$ level was $13.2 \mathrm{~g} / \mathrm{dL}$, with a mean TSAT of $31.9 \%$. The median serum levels of hepcidin and ferritin were $11.8 \mathrm{ng} / \mathrm{mL}$ and $207.2 \mathrm{pmol} / \mathrm{L}$, respectively (Table 1). The prevalence of anemia severity was $45.1 \%$ for $\mathrm{Hb}<13.0 \mathrm{~g} / \mathrm{dL}, 18.8 \%$ for $\mathrm{Hb}<11.5 \mathrm{~g} / \mathrm{dL}$ and $4.2 \%$ for $\mathrm{Hb}<10.0 \mathrm{~g} / \mathrm{dL}$, respectively.

We explored the association between serum hepcidin, iron indices, and anemia severity (Table 2). Regardless of anemia severity, serum hepcidin and iron indices were significantly associated with anemia according to the univariate logistic regression analysis, which was confirmed using the ROC analysis (Fig. 1). During comparisons of AUCs, the predictive power 


\section{Kidney Blood Pressure Research}

Table 1. Baseline characteristics of the study participants. Values are expressed as mean \pm standard deviation for normally distributed continuous variables, median (interquartile range) for non-normally distributed continuous variables, and percentage for categorical variables. Except for smoking status $(10.4 \%)$, income status (2.9\%), high-sensitivity C-reactive protein (4.8\%) and urine protein-to-creatinine ratio $(1.4 \%)$, missing rates of all above variables were $<1.0 \%$

\begin{tabular}{lc}
\hline Characteristics & Total (n =1,677) \\
\hline Age (years) & $53.5 \pm 12.4$ \\
Male sex (\%) & 65.4 \\
High income (\%) & 23.5 \\
Ever smoking (\%) & 48.8 \\
Systolic blood pressure (mm Hg) & $127.4 \pm 15.9$ \\
Diastolic blood pressure (mm Hg) & $77.2 \pm 11.0$ \\
Hypertension (\%) & 95.1 \\
Diabetes (\%) & 25.0 \\
Cause of chronic kidney disease & \\
$\quad$ Diabetic nephropathy (\%) & 22.7 \\
Hypertensive nephropathy (\%) & 32.6 \\
$\quad$ Glomerular nephropathy (\%) & 21.2 \\
$\quad$ Other (\%) & 23.4 \\
Body mass index (kg/m ${ }^{2}$ ) & $24.7 \pm 3.4$ \\
Fasting plasma glucose (mmol/L) & $6.2 \pm 2.2$ \\
Blood urea nitrogen (mmol/L) & $9.1 \pm 4.7$ \\
Creatinine ( $\mu$ mol/L) & $144.4 \pm 83.2$ \\
Estimated glomerular filtration rate (mL/min/1.73m²) & $54.8 \pm 30.2$ \\
Bilirubin ( $\mu$ mol/L) & $12.0 \pm 5.3$ \\
Albumin (g/L) & $42.0 \pm 4.3$ \\
Cholesterol (mmol/L) & $4.6 \pm 1.0$ \\
White blood cells $\left(\times 10^{3} / \mu \mathrm{L}\right)$ & $6.7 \pm 1.9$ \\
Hemoglobin (g/dL) & $13.2 \pm 1.9$ \\
Serum transferrin saturation (\%) & $31.9 \pm 11.9$ \\
Serum hepcidin (ng/mL) & $11.8(6.2-21.5)$ \\
Serum ferritin (pmol/L) & $207.2(115.8-368.4)$ \\
High-sensitivity C-reactive protein $(\mathrm{nmol} / \mathrm{L})$ & $5.7(2.0-15.2)$ \\
\hline
\end{tabular}

Table 2. Association of serum hepcidin and iron indices with anemia severity. Hb, hemoglobin; TSAT, transferrin saturation; OR, odds ratio; CI, confidence interval. OR and its $\mathrm{CI}$ were calculated using logistic regression analysis. In multivariate analysis, TSAT, ferritin and hepcidin were entered into together with age, sex, income status, smoking status, body mass index, fasting plasma glucose, systolic blood pressure, estimated glomerular filtration rate, bilirubin, albumin, and urine protein-to-creatinine ratio. * per $10 \%$ increase in TSAT, per $10 \mathrm{pmol} / \mathrm{L}$ increase in ferritin, and per $10 \mathrm{ng} / \mathrm{mL}$ increase in hepcidin

\begin{tabular}{|c|c|c|c|c|c|}
\hline \multirow[b]{2}{*}{ Outcomes } & \multirow[b]{2}{*}{ Factors* } & \multicolumn{2}{|c|}{ Univariate } & \multicolumn{2}{|c|}{ Multivariate } \\
\hline & & OR $(95 \% \mathrm{CI})$ & $P$ & OR $(95 \% \mathrm{CI})$ & $P$ \\
\hline \multirow[t]{3}{*}{$\mathrm{Hb}<13.0 \mathrm{~g} / \mathrm{dL}$} & TSAT (10 \%) & $0.660(0.602-0.723)$ & $<0.001$ & $0.701(0.610-0.807)$ & $<0.001$ \\
\hline & Ferritin $(10 \mathrm{pmol} / \mathrm{L})$ & $0.995(0.991-0.999)$ & 0.016 & $1.001(0.993-1.008)$ & 0.890 \\
\hline & Hepcidin $(10 \mathrm{ng} / \mathrm{mL})$ & $1.175(1.100-1.255)$ & $<0.001$ & $1.200(1.054-1.367)$ & 0.006 \\
\hline \multirow[t]{3}{*}{$\mathrm{Hb}<11.5 \mathrm{~g} / \mathrm{dL}$} & TSAT $(10 \%)$ & $0.671(0.595-0.756)$ & $<0.001$ & $0.747(0.620-0.901)$ & 0.002 \\
\hline & Ferritin $(10 \mathrm{pmol} / \mathrm{L})$ & $1.001(0.996-1.005)$ & 0.785 & $0.992(0.984-1.001)$ & 0.072 \\
\hline & Hepcidin $(10 \mathrm{ng} / \mathrm{mL})$ & $1.316(1.224-1.413)$ & $<0.001$ & $1.403(1.221-1.613)$ & $<0.001$ \\
\hline \multirow[t]{3}{*}{$\mathrm{Hb}<10.0 \mathrm{~g} / \mathrm{dL}$} & TSAT (10 \%) & $0.765(0.612-0.956)$ & 0.019 & $0.691(0.484-0.986)$ & 0.041 \\
\hline & Ferritin $(10 \mathrm{pmol} / \mathrm{L})$ & $1.010(1.003-1.017)$ & 0.006 & 0.999 (0.988-1.009) & 0.798 \\
\hline & Hepcidin (10 ng/L) & $1.425(1.283-1.583)$ & $<0.001$ & $1.422(1.180-1.713)$ & $<0.001$ \\
\hline
\end{tabular}

of serum hepcidin was inferior to those of TSAT and ferritin when the outcome was $\mathrm{Hb}$ $<13.0 \mathrm{~g} / \mathrm{dL}$. However, as anemia severity increased, the predictive power of serum hepcidin increased, resulting in the largest serum hepcidin AUC among the three variables when the outcome was $\mathrm{Hb}<10.0 \mathrm{~g} / \mathrm{dL}$. During multivariate logistic regression analysis, after adjusting for kidney function (eGFR) and other confounders (age, sex, income status, smoking status, BMI, fasting plasma glucose, systolic blood pressure, bilirubin, UPCR, and albumin), TSAT and 


\section{Kidney Blood Pressure Research}

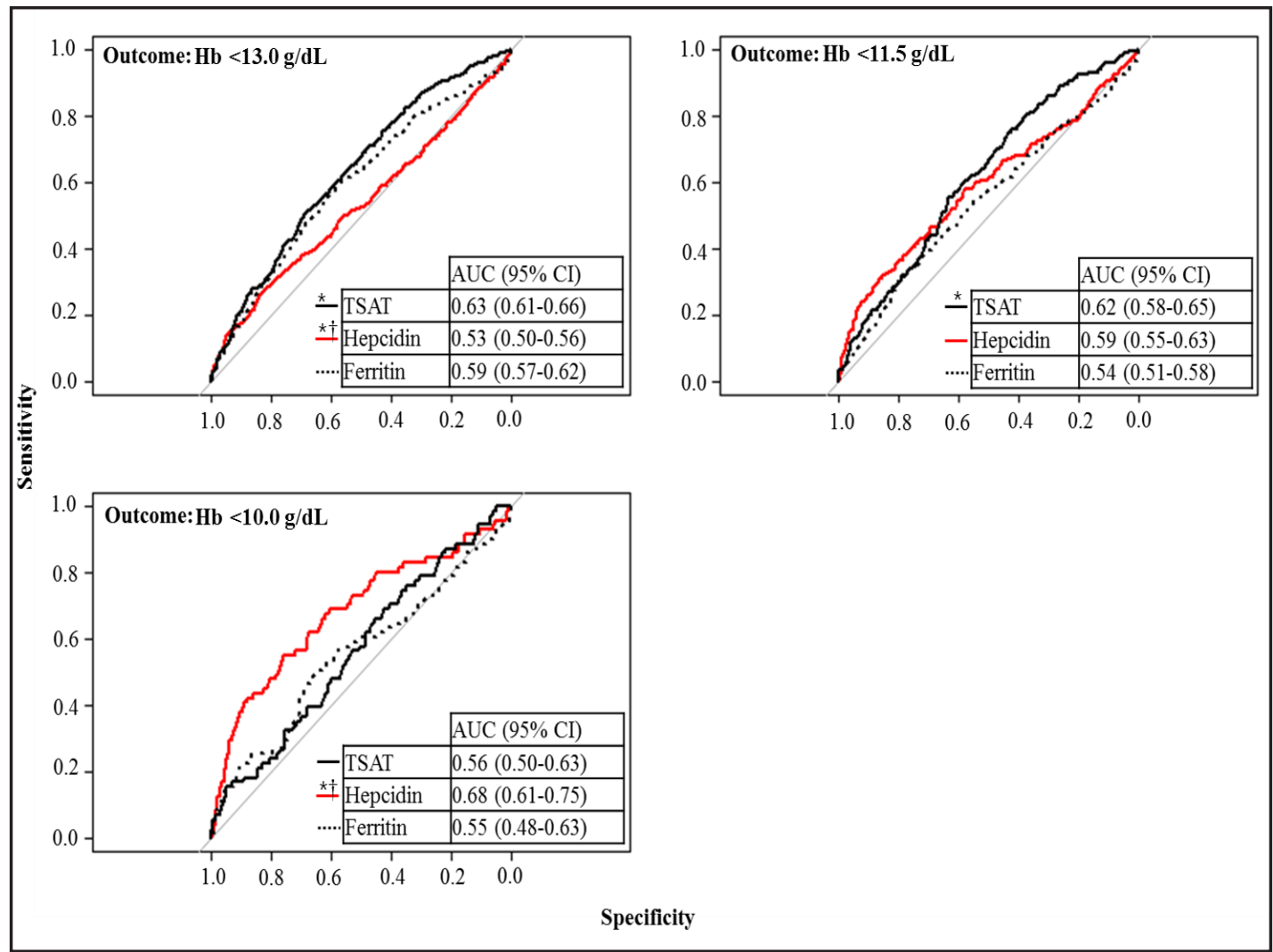

Fig. 1. Receiver-operator characteristics curve analysis of serum hepcidin and iron indexes for anemia severity. AUC, area under the curve; CI, confidence interval; TSAT, transferrin saturation; Hb, hemoglobin. * $\mathrm{P}<0.05$ compared to ferritin and $\uparrow \mathrm{P}<0.05$ compared to TSAT using Delong's test.

serum hepcidin maintained statistical significance, whereas serum ferritin lost statistical significance (Table 2).

We performed a subgroup analysis according to kidney function to evaluate the association between serum hepcidin, iron indices, and anemia severity (Fig. 2). For patients with early CKD ( $n=919)$, the AUC of serum hepcidin for anemia was the smallest among the three variables, regardless of anemia severity. However, for patients with advanced CKD (n =758), the AUC of serum hepcidin increased as anemia severity increased, resulting in the highest AUC when the outcome was $\mathrm{Hb}<10.0 \mathrm{~g} / \mathrm{dL}$. Similar findings were observed during multivariate logistic regression analysis after adjusting for kidney function (eGFR) and other confounders (age, sex, income status, smoking status, BMI, fasting plasma glucose, systolic blood pressure, bilirubin, UPCR, and albumin) (Table 3). For patients with early CKD, serum hepcidin was not associated with anemia, regardless of anemia severity. Among iron indices, only TSAT was significantly associated with anemia; it was particularly associated with less severe anemia $(\mathrm{Hb}<13.0 \mathrm{~g} / \mathrm{dL}$ and $\mathrm{Hb}<11.5 \mathrm{~g} / \mathrm{dL})$. However, for patients with advanced CKD, serum hepcidin was significantly associated with anemia; it was particularly associated with more severe anemia $(\mathrm{Hb}<11.5 \mathrm{~g} / \mathrm{dL}$ and $\mathrm{Hb}<10.0 \mathrm{~g} / \mathrm{dL})$, whereas the effects of TSAT and ferritin on anemia severity were minimal. 


\section{Kidney \\ Blood Pressure Research}

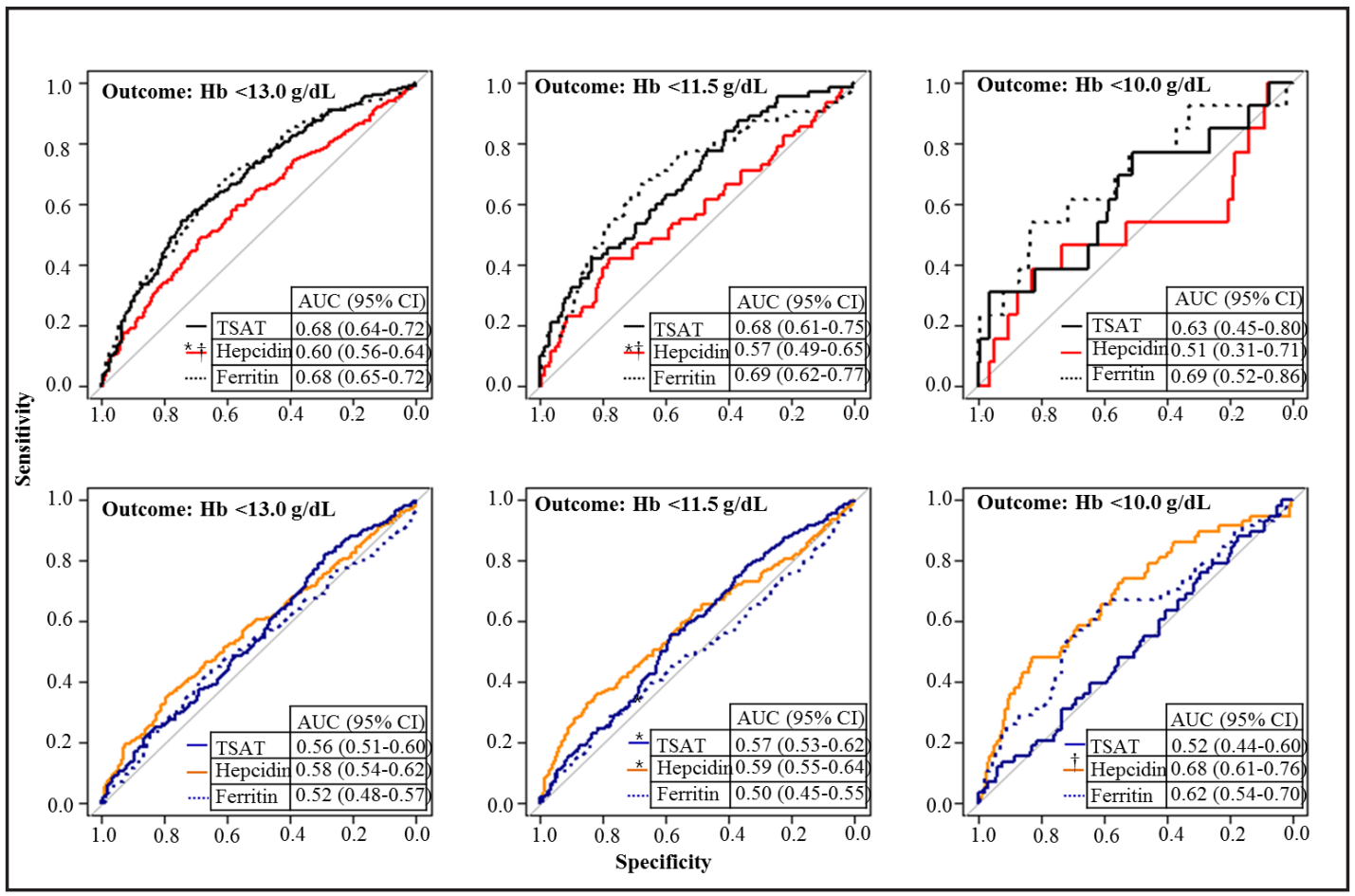

Fig. 2. Subgroup analysis according to the kidney function of the receiver-operator characteristics curve analysis of serum hepcidin and iron indexes for anemia severity. eGFR, estimated glomerular filtration rate; AUC, area under the curve; CI, confidence interval; TSAT, transferrin saturation; Hb, hemoglobin. Upper rows show results of patients with preserved kidney function ( $\mathrm{eGFR} \geq 45 \mathrm{~mL} / \mathrm{min} / 1.73 \mathrm{~m}^{2} ; \mathrm{n}=919$ ) and lower rows show results of patients with decreased kidney function (eGFR $<45 \mathrm{~mL} / \mathrm{min} / 1.73 \mathrm{~m}^{2} ; \mathrm{n}=758$ ). * $\mathrm{P}<0.05$ compared to ferritin and $\dagger \mathrm{P}<0.05$ compared to TSAT using Delong's test.

Table 3. Subgroup analysis according to the kidney function for the association of serum hepcidin and iron indices with anemia severity. Hb, hemoglobin; TSAT, transferrin saturation; Adj. OR, adjusted odds ratio; $\mathrm{CI}$, confidence interval. Adj. OR and its CI were calculated using multivariate logistic regression analysis. TSAT, ferritin and hepcidin were entered into together with age, sex, income status, smoking status, body mass index, fasting plasma glucose, systolic blood pressure, estimated glomerular filtration rate, bilirubin, albumin, and urine protein-to-creatinine ratio. * per $10 \%$ increase in TSAT, per 10 pmol/L increase in ferritin, and per $10 \mathrm{ng} / \mathrm{mL}$ increase in hepcidin

\begin{tabular}{|c|c|c|c|c|c|}
\hline \multirow[b]{3}{*}{ Outcomes } & \multirow[b]{3}{*}{ Factors* } & \multicolumn{4}{|c|}{ Estimate glomerular filtration rate } \\
\hline & & \multicolumn{2}{|c|}{$\geq 45 \mathrm{~mL} / \mathrm{min} / 1.73 \mathrm{~m}^{2}(\mathrm{n}=919)$} & \multicolumn{2}{|c|}{$<45 \mathrm{~mL} / \mathrm{min} / 1.73 \mathrm{~m}^{2}(\mathrm{n}=758)$} \\
\hline & & Adj. OR $(95 \% \mathrm{CI})$ & $\mathrm{P}$ & Adj.OR (95\% CI) & $\mathrm{P}$ \\
\hline \multirow[t]{3}{*}{$\mathrm{Hb}<13.0 \mathrm{~g} / \mathrm{dL}$} & TSAT (10 \%) & $0.628(0.515-0.765)$ & $<0.001$ & $0.805(0.648-0.998)$ & 0.048 \\
\hline & Ferritin $(10 \mathrm{pmol} / \mathrm{L})$ & $0.997(0.984-1.011)$ & 0.677 & $1.008(0.997-1.019)$ & 0.179 \\
\hline & Hepcidin $(10 \mathrm{ng} / \mathrm{mL})$ & $1.112(0.887-1.394)$ & 0.357 & $1.138(0.946-1.369)$ & 0.172 \\
\hline \multirow[t]{3}{*}{$\mathrm{Hb}<11.5 \mathrm{~g} / \mathrm{dL}$} & $\operatorname{TSAT}(10 \%)$ & $0.672(0.476-0.950)$ & 0.024 & $0.791(0.626-1.001)$ & 0.051 \\
\hline & Ferritin $(10 \mathrm{pmol} / \mathrm{L})$ & $1.006(0.983-1.030)$ & 0.592 & $0.993(0.984-1.003)$ & 0.166 \\
\hline & Hepcidin $(10 \mathrm{ng} / \mathrm{mL})$ & $1.060(0.684-1.642)$ & 0.794 & $1.379(1.173-1.620)$ & $<0.001$ \\
\hline \multirow[t]{3}{*}{$\mathrm{Hb}<10.0 \mathrm{~g} / \mathrm{dL}$} & TSAT $(10 \%)$ & $0.350(0.116-1.058)$ & 0.063 & $0.717(0.477-1.078)$ & 0.110 \\
\hline & Ferritin $(10 \mathrm{pmol} / \mathrm{L})$ & $1.022(0.970-1.077)$ & 0.417 & $1.002(0.991-1.014)$ & 0.726 \\
\hline & Hepcidin $(10 \mathrm{ng} / \mathrm{mL})$ & $1.293(0.377-4.436)$ & 0.683 & $1.360(1.115-1.659)$ & 0.002 \\
\hline
\end{tabular}




\section{Kidney Blood Pressure Research}

Lee et al.: Serum Hepcidin and Anemia of CKD

\section{Discussion}

Iron metabolism has been suggested as a key factor contributing to anemia in CKD patients $[10,11]$. Anemia guidelines for CKD patients consider that TSAT and ferritin are important markers of anemia in CKD, and they recommend iron replacement according to TSAT and ferritin serum levels $[9,37]$. Hepcidin has been suggested as a good biomarker of anemia in CKD patients [21-33]. Hepcidin lowers the available serum iron levels by limiting iron efflux from the body's iron stores [19]; therefore, it is plausible that iron should be sequestrated in iron stores as the serum hepcidin level increases. This may cause bone marrow iron deficiency despite sufficient iron in storage sites [40], suggesting that sufficient serum levels of TSAT and ferritin may not guarantee sufficient production of RBC when the serum hepcidin level is increased. Our study group recently reported that kidney function was one of the major determinants of the serum hepcidin level, thereby suggesting serum hepcidin as a novel uremic toxin [20]. We hypothesized that serum hepcidin and iron indices associated with anemia are affected by kidney function. Because iron sequestration by hepcidin can result in a profound decrease in RBC production [41], we also hypothesized that anemia associated with hepcidin is more severe than anemia associated with iron indices.

In this study, serum ferritin levels were not associated with anemia status. Although the serum ferritin level of CKD patients was associated with hepatosplenic iron stores [40], it was not correlated with bone marrow iron stores [15, 40,42]. This so-called iron sequestration in CKD patients may result in a null association between serum ferritin and anemia status in our study participants. This null association between serum ferritin and anemia status was evident even in patients with early CKD, thus implying that iron sequestration in CKD patients may occur during the early stage of CKD. Hepcidin is a fundamental peptide in iron sequestration, and serum hepcidin levels in CKD patients are higher than those of healthy volunteers [43, 44]. Serum hepcidin levels also increased with CKD progression [20]. Therefore, we can hypothesize that a small increase in serum hepcidin even during early CKD may nullify the effect of serum ferritin on Hb levels.

In the current study, unlike ferritin, TSAT was significantly associated with anemia, which was in accordance with the fact that TSAT is more predictive of bone marrow iron contents [15] and the $\mathrm{Hb}$ response after intravenous iron replacement [45] than ferritin in CKD patients. Serum hepcidin was also significantly associated with anemia in non-dialysis CKD patients. These associations were independent from kidney function. Because of the large sample size, we could further analyze the kidney function. During the analysis, TSAT was associated with less severe anemia in patients with early CKD, whereas serum hepcidin was significantly related to more severe anemia in patients with advanced CKD. These results suggested that TSAT is a major determinant of anemia in early CKD patients, whereas serum hepcidin is a key determinant of anemia in advanced CKD patients.

We also found that serum hepcidin and iron indices were not associated with $\mathrm{Hb}<10.0 \mathrm{~g} /$ $\mathrm{dL}$ in patients with early CKD. This may imply that serum hepcidin levels in early CKD patients were not high enough to cause profound decreases in $\mathrm{Hb}$ [20]. In addition, decreases in TSAT and ferritin in early CKD patients may not be sufficient to result in decreases in $\mathrm{Hb}<10.0$ $\mathrm{g} / \mathrm{dL}$. Therefore, clinicians should rule out other causes of anemia such as gastrointestinal bleeding [12] in patients with early CKD, when Hb levels are decreased profoundly.

We hypothesized that increased serum hepcidin levels may sequentially nullify the effects of iron indices on anemia (ferritin first and TSAT later). For early CKD patients, the serum hepcidin level may be enough to nullify the effect of ferritin on anemia, causing iron sequestration; however, this level may not be enough to diminish the effect of TSAT on anemia. This may be why only TSAT was associated with less severe anemia during early CKD. As CKD progresses, the serum hepcidin level increases, and the increased serum hepcidin level may be high enough to incapacitate the effect of TSAT on RBC production in advanced CKD patients. Very high hepcidin will sequestrate iron profoundly enough to cause severe 


\section{Kidney \\ Blood Pressure Research}

anemia. However, this new hypothesis needs to be confirmed using future experimental and human studies.

This study had several limitations. First, because the study was cross-sectional, a causal relationship could not be accurately determined, and the results need to be interpreted carefully. However, most previous studies regarding hepcidin were cross-sectional studies, because drugs specifically targeting hepcidin are not currently available for humans $[14,19]$. To our knowledge, the current study used the largest sample to examine the associations between hepcidin, iron indices and anemia. Therefore, this study limitation may be acceptable. Second, we did not have data regarding the causes of anemia because KNOW-CKD was not designed specifically for anemia in CKD patients. Furthermore, there were no data from healthy volunteers and patients with ESRD on dialysis. In addition, the study was performed in a single country and involved a single ethnicity, thus limiting the generalizability of the results.

In conclusion, ferritin was not associated with anemia, regardless of its severity, or the level of kidney function. TSAT was associated with less severe anemia in patients with early CKD. However, serum hepcidin was associated with more severe anemia in patients with advanced CKD. These results need to be confirmed using future studies.

\section{Disclosure Statement}

The authors have declared that no competing interests exist.

\section{Acknowledgements}

This study was supported by the Research Program funded by the Korea Center for Disease Control and Prevention (2011E3300300, 2012E3301100, 2013E3301600, 2013E3301601, 2013E3301602, and 2016E3300200).

\section{References}

1 Stauffer ME, Fan T: Prevalence of anemia in chronic kidney disease in the United States. PLoS One 2014;9:e84943.

-2 Ryu SR, Park SK, Jung JY, Kim YH, Oh YK, Yoo TH, Sung S: The Prevalence and Management of Anemia in Chronic Kidney Disease Patients: Result from the KoreaN Cohort Study for Outcomes in Patients With Chronic Kidney Disease (KNOW-CKD). J Korean Med Sci 2017;32:249-256.

-3 Portoles J, Gorriz JL, Rubio E, de Alvaro F, Garcia F, Alvarez-Chivas V, Aranda P, Martinez-Castelao A, NADIR-3 Study Group: The development of anemia is associated to poor prognosis in NKF/KDOQI stage 3 chronic kidney disease. BMC Nephrol 2013;14:2.

4 Kovesdy CP, Trivedi BK, Kalantar-Zadeh K, Anderson JE: Association of anemia with outcomes in men with moderate and severe chronic kidney disease. Kidney Int 2006;69:560-564.

5 Webster AC, Nagler EV, Morton RL, Masson P: Chronic Kidney Disease. Lancet 2017;389:1238-1252.

-6 Singh AK, Szczech L, Tang KL, Barnhart H, Sapp S, Wolfson M, Reddan D, CHOIR Investigators: Correction of anemia with epoetin alfa in chronic kidney disease. N Engl J Med 2006;355:2085-2098.

-7 Pfeffer MA, Burdmann EA, Chen CY, Cooper ME, de Zeeuw D, Eckardt KU, Feyzi JM, Ivanovich P, Kewalramani R, Levey AS, Lewis EF, McGill JB, McMurray JJ, Parfrey P, Parving HH, Remuzzi G, Singh AK, Solomon SD, Toto $\mathrm{R}, \mathrm{TREAT}$ Investigators: A trial of darbepoetin alfa in type 2 diabetes and chronic kidney disease. $\mathrm{N}$ Engl J Med 2009;361:2019-2032. 


\section{Kidney \\ Blood Pressure Research}

Lee et al.: Serum Hepcidin and Anemia of CKD

-8 Locatelli F, Barany P, Covic A, De Francisco A, Del Vecchio L, Goldsmith D, Horl W, London G, Vanholder R, Van Biesen W, ERA-EDTA ERBP Advisory Board: Kidney Disease: Improving Global Outcomes guidelines on anaemia management in chronic kidney disease: a European Renal Best Practice position statement. Nephrol Dial Transplant 2013;28:1346-1359.

-9 Kidney Disease Outcomes Quality Initiative: KDOQI Clinical Practice Guideline and Clinical Practice Recommendations for anemia in chronic kidney disease: 2007 update of hemoglobin target. Am J Kidney Dis 2007;50:471-530.

10 Ganz T: Molecular control of iron transport. J Am Soc Nephrol 2007;18:394-400.

11 van der Putten K, Braam B, Jie KE, Gaillard CA: Mechanisms of Disease: erythropoietin resistance in patients with both heart and kidney failure. Nat Clin Pract Nephrol 2008;4:47-57.

12 Fishbane S: Iron management in nondialysis-dependent CKD. Am J Kidney Dis 2007;49:736-743.

13 Bahrainwala J, Berns JS: Diagnosis of Iron-Deficiency Anemia in Chronic Kidney Disease. Semin Nephrol 2016;36:94-98.

14 Babitt JL, Lin HY: Molecular mechanisms of hepcidin regulation: implications for the anemia of CKD. Am J Kidney Dis 2010;55:726-741.

15 Stancu S, Stanciu A, Zugravu A, Barsan L, Dumitru D, Lipan M, Mircescu G: Bone marrow iron, iron indices, and the response to intravenous iron in patients with non-dialysis-dependent CKD. Am J Kidney Dis 2010;55:639-647.

16 Kalantar-Zadeh K, Hoffken B, Wunsch H, Fink H, Kleiner M, Luft FC: Diagnosis of iron deficiency anemia in renal failure patients during the post-erythropoietin era. Am J Kidney Dis 1995;26:292-299.

17 Fishbane S, Kowalski EA, Imbriano LJ, Maesaka JK: The evaluation of iron status in hemodialysis patients. J Am Soc Nephrol 1996;7:2654-2657.

18 Tessitore N, Solero GP, Lippi G, Bassi A, Faccini GB, Bedogna V, Gammaro L, Brocco G, Restivo G, Bernich P, Lupo A, Maschio G: The role of iron status markers in predicting response to intravenous iron in haemodialysis patients on maintenance erythropoietin. Nephrol Dial Transplant 2001;16:1416-1423.

19 Ganz T: Hepcidin and iron regulation, 10 years later. Blood 2011;117:4425-4433.

20 Lee SW, Kim JM, Lim HJ, Hwang YH, Kim SW, Chung W, Oh KH, Ahn C, Lee KB, Sung SA: Serum hepcidin may be a novel uremic toxin, which might be related to erythropoietin resistance. Sci Rep 2017;7:4260.

21 Zaritsky J, Young B, Wang HJ, Westerman M, Olbina G, Nemeth E, Ganz T, Rivera S, Nissenson AR, Salusky IB: Hepcidin--a potential novel biomarker for iron status in chronic kidney disease. Clin J Am Soc Nephrol 2009;4:1051-1056.

22 Uehata T, Tomosugi N, Shoji T, Sakaguchi Y, Suzuki A, Kaneko T, Okada N, Yamamoto R, Nagasawa Y, Kato K, Isaka Y, Rakugi H, Tsubakihara Y: Serum hepcidin-25 levels and anemia in non-dialysis chronic kidney disease patients: a cross-sectional study. Nephrol Dial Transplant 2012;27:1076-1083.

23 Niihata K, Tomosugi N, Uehata T, Shoji T, Mitsumoto K, Shimizu M, Kawabata H, Sakaguchi Y, Suzuki A, Hayashi T, Okada N, Isaka Y, Rakugi H, Tsubakihara Y: Serum hepcidin-25 levels predict the progression of renal anemia in patients with non-dialysis chronic kidney disease. Nephrol Dial Transplant 2012;27:43784385.

24 Mercadal L, Metzger M, Haymann JP, Thervet E, Boffa JJ, Flamant M, Vrtovsnik F, Houillier P, Froissart M, Stengel B, NephroTest Study Group: The relation of hepcidin to iron disorders, inflammation and hemoglobin in chronic kidney disease. PLoS One 2014;9:e99781.

-25 Atkinson MA, Kim JY, Roy CN, Warady BA, White CT, Furth SL: Hepcidin and risk of anemia in CKD: a crosssectional and longitudinal analysis in the CKiD cohort. Pediatr Nephrol 2015;30:635-643.

-26 Drakou A, Margeli A, Theodorakopoulou S, Agrogiannis I, Poziopoulos C, Papassotiriou I, Vlahakos DV: Assessment of serum bioactive hepcidin-25, soluble transferrin receptor and their ratio in predialysis patients: Correlation with the response to intravenous ferric carboxymaltose. Blood Cells Mol Dis 2016;59:100-105.

27 Gaillard CA, Bock AH, Carrera F, Eckardt KU, Van Wyck DB, Bansal SS, Cronin M, Meier Y, Larroque S, Roger SD, Macdougall IC: Hepcidin Response to Iron Therapy in Patients with Non-Dialysis Dependent CKD: An Analysis of the FIND-CKD Trial. PLoS One 2016;11:e0157063.

28 Lukaszyk E, Lukaszyk M, Koc-Zorawska E, Tobolczyk J, Bodzenta-Lukaszyk A, Malyszko J: Iron Status and Inflammation in Early Stages of Chronic Kidney Disease. Kidney Blood Press Res 2015;40:366-373. 


\section{Kidney \\ Blood Pressure Research}

Lee et al.: Serum Hepcidin and Anemia of CKD

29 Malyszko J, Malyszko JS, Hryszko T, Pawlak K, Mysliwiec M: Is hepcidin a link between anemia, inflammation and liver function in hemodialyzed patients? Am J Nephrol 2005;25:586-590.

-30 Tomosugi N, Kawabata H, Wakatabe R, Higuchi M, Yamaya H, Umehara H, Ishikawa I: Detection of serum hepcidin in renal failure and inflammation by using ProteinChip System. Blood 2006;108:1381-1387.

-31 Malyszko J, Malyszko JS, Pawlak K, Mysliwiec M: Hepcidin, iron status, and renal function in chronic renal failure, kidney transplantation, and hemodialysis. Am J Hematol 2006;81:832-837.

-32 Malyszko J, Malyszko JS, Pawlak K, Mysliwiec M: Hepcidin, an acute-phase protein and a marker of inflammation in kidney transplant recipients with and without coronary artery disease. Transplant Proc 2006;38:2895-2898.

33 Kato A, Tsuji T, Luo J, Sakao Y, Yasuda H, Hishida A: Association of prohepcidin and hepcidin-25 with erythropoietin response and ferritin in hemodialysis patients. Am J Nephrol 2008;28:115-121.

-34 Oh KH, Park SK, Park HC, Chin HJ, Chae DW, Choi KH, Han SH, Yoo TH, Lee K, Kim YS, Chung W, Hwang YH, Kim SW, Kim YH, Kang SW, Park BJ, Lee J, Ahn C: KNOW-CKD (KoreaN cohort study for Outcome in patients With Chronic Kidney Disease): design and methods. BMC Nephrol 2014;15:80.

-35 Levey AS, Coresh J, Greene T, Stevens LA, Zhang YL, Hendriksen S, Kusek JW, Van Lente F: Using standardized serum creatinine values in the modification of diet in renal disease study equation for estimating glomerular filtration rate. Ann Intern Med 2006;145:247-254.

-36 Stevens PE, Levin A, Kidney Disease: Improving Global Outcomes Chronic Kidney Disease Guideline Development Work Group M: Evaluation and management of chronic kidney disease: synopsis of the kidney disease: improving global outcomes 2012 clinical practice guideline. Ann Intern Med 2013;158:825830.

37 KDIGO group: KDIGO Clinical Practice Guideline for Anemia in Chronic Kidney Disease. Kidney Int Suppl 2012;2:279-335.

-38 Robin X, Turck N, Hainard A, Tiberti N, Lisacek F, Sanchez JC, Muller M: pROC: an open-source package for R and S+ to analyze and compare ROC curves. BMC Bioinformatics 2011;12:77.

39 DeLong ER, DeLong DM, Clarke-Pearson DL: Comparing the areas under two or more correlated receiver operating characteristic curves: a nonparametric approach. Biometrics 1988;44:837-845.

40 Ali M, Rigolosi R, Fayemi AO, Braun EV, Frascino J, Singer R: Failure of serum ferritin levels to predict bonemarrow iron content after intravenous iron-dextran therapy. Lancet 1982;1:652-655.

-41 Hanudel MR, Rappaport M, Gabayan V, Jung G, Salusky IB, Nemeth E, Ganz T, Zaritsky J: Increased serum hepcidin contributes to the anemia of chronic kidney disease in a murine model. Haematologica 2017;102:e85-e88.

42 Gotloib L, Silverberg D, Fudin R, Shostak A: Iron deficiency is a common cause of anemia in chronic kidney disease and can often be corrected with intravenous iron. J Nephrol 2006;19:161-167.

43 Yang LN, Zhang P, Tang F, Wang G, Li FE: Correlation between hepcidin level and renal anemia. Genet Mol Res 2014;13:7407-7410.

44 Troutt JS, Butterfield AM, Konrad RJ: Hepcidin-25 concentrations are markedly increased in patients with chronic kidney disease and are inversely correlated with estimated glomerular filtration rates. J Clin Lab Anal 2013;27:504-510.

45 Singh AK, Coyne DW, Shapiro W, Rizkala AR, DRIVE Study Group: Predictors of the response to treatment in anemic hemodialysis patients with high serum ferritin and low transferrin saturation. Kidney Int 2007;71:1163-1171. 